\title{
Transfer of the Type Species of the Genus Methanococcus to the Genus Methanosarcina, Naming it Methanosarcina mazei (Barker 1936) comb. nov. et emend. and Conservation of the Genus Methanococcus (Approved Lists 1980) with Methanococcus vannielii (Approved Lists 1980) as the Type Species
}

\author{
Request for an Opinion \\ ROBERT A. MAH ${ }^{1 *}$ AND DAISY A. KUHN ${ }^{2}$ \\ Division of Environmental and Occupational Health Sciences, School of Public Health, University of California, Los \\ Angeles, California $90024^{1}$ and Department of Biology, California State University, Northridge, California $91330^{2}$
}

Mah (Curr. Microbiol. 3:321-326, 1980) isolated Methanococcus mazei, a methanogen that was first described by Barker in 1936. The current characterization of this organism demands transfer of it to the genus Methanosarcina. We present an emended description of Methanosarcina mazei comb. nov. Since Methanococcus mazei (Approved Lists 1980) is the type species of the genus Methanococcus and its removal invalidates the genus, we request an Opinion from the Judicial Commission to remove the type species from the genus Methanococcus and to conserve this genus with Methanococcus vannielii as the type species, as suggested by Balch et al. (Microbiol. Rev. 43:260-296, 1979).

This Request for an Opinion is presented in the following two parts: (i) an emended description of Methanosarcina mazei comb. nov. based on the isolation and characterization of an axenic strain of the organism; and (ii) justification for the conservation of the genus Methanococcus demanded by the taxonomic transfer of the type species, Methanococcus mazei, to the genus Methanosarcina. This transfer of the type species would otherwise invalidate the genus Methanococcus.

Methanosarcina mazei comb. nov. et emend. On the Approved Lists of Bacterial Names (11), which became effective on 1 January 1980, Methanococcus mazei Barker 1936 was listed as the type species of the genus Methanococcus Kluyver and van Niel 1936 emend. Barker 1936; a type strain was not extant.

The genus Methanococcus was created by Kluyver and van Niel (7) in 1936 to accommodate the relatively small methanogenic cocci described by Groenewege (6) in 1920. These small cocci formed "considerable masses," were embedded in a "slimy matrix," and were thought "to ferment methyl and butyl alcohols and acetone in addition to ethyl alcohol"' (3). In cultures with ethanol as the substrate, they overgrew "all other types of methane bacteria" (3). These cocci were morphologically distinct from the organisms for which Kluyver and van Niel (7) created the genus Methanosarcina. At that time, no axenic culture of any methanogenic bacterium existed.

When Kluyver and van Niel (7) named the genus Methanococcus, they did not name a species; therefore, this genus name was not validly published according to the International Code of Nomenclature of Bacteria (8), and a nomenclatural type species of the genus did not exist. However, Kluyver and van Niel stated in their description of the genus, "The type species to be assigned in the near future" (7). Later that year, Barker (3), who was working in the laboratory of

\footnotetext{
* Corresponding author.
}

Kluyver and van Niel, described a methanogenic coccoid organism that was present in enriched but not axenic cultures, recognized the generic name Methanococcus published by Kluyver and van Niel (7), and named the organism Methanococcus mazei (3). Thus, in 1936 Methanococcus mazei was the first and only named species of the genus Methanococcus (Methanococcus vannielii was not named until 1951 by Stadtman and Barker [12]), and with "later general acceptance" (Rule 20e, Opinion 20 of the International Code [8]), Methanococcus mazei was cited as the type species of the genus Methanococcus by Barker in 1957 in Bergey's Manual of Determinative Bacteriology, 7th ed. (4), and by Bryant in 1974 in Bergey's Manual, 8th ed. (5). The Approved Lists of Bacterial Names (11), which became effective on 1 January 1980, included Methanococcus mazei Barker 1936 as type species of the genus Methanococcus Kluyver and van Niel 1936 emend. Barker 1936.

The original description of Methanococcus mazei by Barker (3) contained detailed photomicrographs of various stages of the life cycle, including single small spherical cells, irregular masses, and "cysts" of various sizes and shapes. However, because the description of Methanococcus mazei of Barker was not based on axenic cultures, some doubt was cast on these and other characteristics, especially the ability of the organism to utilize alcohols and acetone as substrates.

Recent isolation of Methanococcus mazei in axenic culture (9) confirmed most of the findings of Barker, particularly some of the characteristic morphological stages. This axenic culture differs from the description of Barker in substrate utilization. In addition to acetate, the following substrates are used for methanogenesis: methanol, methylamine, trimethylamine, and $\mathrm{H}_{2}-\mathrm{CO}_{2}$. Butyrate, higher alcohols, and acetone are not used.

Morphologically, the axenic culture of Methanococcus mazei exhibits a life cycle (9). In young cultures, individual coccoid cells develop into large Methanosarcina-like aggregates. These become cysts, which in turn can release individual coccoid elements. These stages in the life cycle of 
Methanococcus mazei resemble two of the biotypes (biotypes 1 and 3) described by Zhilina and Zavarzin (14). Zhilina (13) identified three biotypes (called biotypes or morphotypes by Zhilina) in the genus Methanosarcina. Biotype 1 is composed of large, irregular multiunit aggregates; biotype 2 is made up of smaller clusters; and biotype 3 is composed of small individual coccoid elements. Barker (3) chose the name Methanococcus mazei because of the predominance of individual coccoid cells (biotype 3 ) which occurred in his enrichment cultures. However, the irregular multiunit aggregates (biotype 1) which characterize the young, axenic cultures of Methanococcus mazei (9) were not mentioned by Barker (3) or by Zhilina and Zavarzin (14). These forms (biotype 1) were like those previously described by Mazé as "pseudo-sarcine" (10). Mah (9) showed that axenic cultures of Methanococcus mazei biotype 1 (which resemble Methanosarcina sp. strain TM-1 described by Zinder and Mah [15]) gives rise to oval bodies described as cysts by Barker (3) (called macrocysts by Zhilina and Zavarzin [14]), which can be ruptured to release individual coccoid elements (biotype 3 [13]). Thus, during its early growth cycle, Methanococcus mazei is morphologically indistinguishable from some Methanosarcina strains (e.g., strain TM-1, which has biotype 1 morphology). Apparently, Methanosarcina barkeri and other previously reported methanosarcinae do not release their individual constituent elements and cannot undergo complete life cycles.

Physiologically, the axenic strain of Methanococcus mazei metabolizes methanogenic substrates (acetate, methanol, methylamine, trimethylamine) similar to those metabolized by all known strains of Methanosarcina barkeri. However, Methanococcus mazei differs significantly from these strains by its ability to use acetate or methanol much more rapidly than $\mathrm{H}_{2}-\mathrm{CO}_{2}$, which it uses very slowly or not at all. In most of the remaining genera of methanogenic bacteria, including the two species of the genus Methanococcus (Methanococcus vannielii and Methanococcus voltae), only $\mathrm{H}_{2}-\mathrm{CO}_{2}$ and occasionally formate are used for methanogenesis.

Finally, the recent finding by Woese and Wolfe (personal communication) of an $S_{\mathrm{AB}}$ value of 0.8 (an association coefficient [2] based on the degree of $16 \mathrm{~S}$ ribosomal ribonucleic acid homology) in a binary comparison of Methanococcus mazei DSM $2053^{\mathrm{T}}$ ( $\mathrm{T}=$ type strain) and Methanosarcina barkeri DSM $800^{\mathrm{T}}$ leaves little doubt regarding the close relationship between these two species. For these reasons, we propose transfer of Methanococcus mazei to the genus Methanosarcina, and we present the following emended description of Methanosarcina mazei comb. nov.

Methanosarcina mazei (Barker 1936) comb. nov. et emend. (Methanococcus mazei Barker 1936, 433 (3); "Pseudosarcina" Mazé 1915, 398 [4, 5]) (ma'ze.i. N.L. gen. n. mazei of Mazé, named for P. Mazé, the French bacteriologist who first studied the organism). Individual, irregular coccoid cells 1.0 to $3.0 \mu \mathrm{m}$ in diameter form irregular clumps 20 to $100 \mu \mathrm{m}$ or more in diameter. These irregular clumps may cluster together in large rafts $1,000 \mu \mathrm{m}$ or more in diameter. The clumps later become cysts, which may give rise to individual coccoid cells. A life cycle involving these morphological stages may occur.

In roll tubes, colonies on acetate medium are buff white to tannish yellow, with a grainy appearance in young cultures ( $<7$ days); older colonies ( $>7$ days) have a smooth appearance, and surface colonies are circular, glistening, mucoid, and pulvinate with entire margins. Occasionally, gas is trapped in the mucoid colony surface, fulminating into clusters of bubbles.
Acetate, methanol, methylamine, and trimethylamine are converted to methane. Either acetate or methanol is used more rapidly than $\mathrm{H}_{2}-\mathrm{CO}_{2} \cdot \mathrm{H}_{2}-\mathrm{CO}_{2}$ is used very slowly or not at all. Butyrate, ethanol, and butanol are not methanogenic.

Methanogenic substrates are utilized as sole energy sources in the presence of yeast extract and Trypticase (BBL Microbiology Systems); stimulated by sludge supernatant. Ammonia may serve as a nitrogen source.

Grows between 30 and $40^{\circ} \mathrm{C}$ and between $\mathrm{pH} 6.1$ and 8.0; optimum growth at $\mathrm{pH} 7.0$.

The estimated generation times on substrates during exponential methane formation are as follows: $1 \%$ methanol, 7.7 $\mathrm{h} ; 0.05 \%$ methanol in combination with $1 \%$ acetate, $7.7 \mathrm{~h}$; $1 \%$ acetate, $16.6 \mathrm{~h}$.

The deoxyribonucleic acid base composition of strain DSM $2053^{\mathrm{T}}$ (= strain $\mathrm{S}-6^{\mathrm{T}}$ ) is $42 \mathrm{~mol} \%$ guanine plus cytosine, as determined by the buoyant density method. The $S_{\mathrm{AB}}$ value in a binary comparison with Methanosarcina barkeri DSM $800^{\mathrm{T}}$ is 0.8 .

Habitat: garden soil, sewage sludge, black mud, and feces of herbivorous animals; also isolated from urban solid waste and various sewage and animal waste digesters, swine waste lagoons, and kelp enrichments.

The type strain of Methanococcus mazei is strain DSM 2053 (= strain S-6), which was isolated from an anaerobic sewage digester.

Conservation of the genus Methanococcus. Transfer of Methanococcus mazei to the genus Methanosarcina removes the type species from the genus Methanococcus. Thus, according to Rule $37 \mathrm{a}$ of the International Code (8), the genus Methanococcus is invalidated unless an Opinion from the Judicial Commission of the International Committee on Systematic Bacteriology rules to the contrary. We present here a Request for an Opinion to conserve the genus Methanococcus in its current taxonomic conception by adopting Methanococcus vannielii as the type species.

In 1979, Balch et al. (2) listed Methanococcus vannielii Stadtman and Barker 1951 (12) as the type species in their emended description of the genus Methanococcus, probably because Methanococcus mazei was not isolated axenically until 1980 (9) and had been omitted from the first draft of the Approved Lists of Bacterial Names published in 1976 (1). The inclusion of Methanococcus mazei on the definitive Approved Lists of Bacterial Names, which became effective on 1 January 1980 , validates its nomenclatural standing (Rule 24a). We propose that the emended description of the genus Methanococcus by Balch et al. (2) be accepted as the concept of the genus Methanococcus. According to Rules $20 \mathrm{e}$ and 36, the genus Methanococcus is ascribed to Stadtman and Barker (12) as emended by Balch et al. (2) instead of Kluyver and van Niel 1936 emend. Barker 1936 (Approved List 1980) (11).

Methanococcus Stadtman and Barker 1951, 269 emend. Balch et al. 1979, 285 (Me.tha.no.coc'cus. N.L. n. methanum methane; N.L. n. coccus spherical cell; N.L. masc. n. Methanococcus methane coccus). Cells are fragile, regular to irregular cocci that are 0.5 to $5 \mu \mathrm{m}$ in diameter and occur singly or in pairs. Cells are highly motile (flagella may be inserted in clusters) and gram negative. There is a single layer of protein subunits external to the plasma membrane. Muramic acid not detected. Ether-linked polyisoprenoid (branched) chain lipids are the predominant lipid components.

Very strict anaerobes. Energy for growth is obtained by oxidation of $\mathrm{H}_{2}$ or formate with reduction of $\mathrm{CO}_{2}$ to $\mathrm{CH}_{4}$. 
Cells contain coenzyme $M$ and coenzyme $F_{420}$. Carbohydrates, proteinaceous material, and organic compounds other than formate are not used as energy sources. Yeast extract is stimulatory, and Se and $\mathrm{W}$ may be stimulatory for growth. May require 1.2 to $4.8 \% \mathrm{NaCl}$. May be osmotically fragile.

The optimal growth temperature is between 32 and $40^{\circ} \mathrm{C}$; the optimal $\mathrm{pH}$ varies with species from $\mathrm{pH} 6.7$ to 9.0 .

The deoxyribonucleic acid base composition is $31 \mathrm{~mol} \%$ guanine plus cytosine (determined for Methanococcus voltae DSM $153^{\mathrm{T}}$ and Methanococcus vannielii DSM $1224^{\mathrm{T}}$ ), as determined by the buoyant density method.

The type species is Methanococcus vannielii Stadtman and Barker 1951, 269 (Approved Lists 1980).

This emended description of the genus Methanococcus does not include the previous morphological description of cocci occurring in masses and restricts the utilization of substrates to $\mathrm{H}_{2}-\mathrm{CO}_{2}$ and formate. Acetate is no longer included as a methanogenic substrate. Thus, any aceticlastic coccoid methanogens which may be isolated in the future will be excluded from the genus Methanococcus. The proposal of Methanococcus vannielii as the type species is consistent with this emended description of morphology and substrate utilization for members of the genus Methanococcus.

\section{ACKNOWLEDGMENT}

We thank David R. Boone for perusing our manuscript.

\section{LITERATURE CITED}

1. Ad Hoc Committee of the Judicial Commission of the ICSB. 1976. First draft. Approved lists of bacterial names. Int. J. Syst. Bacteriol. 26:563-599.

2. Balch, W. E., G. E. Fox, L. J. Magrum, C. R. Woese, and R. S.
Wolfe. 1979. Methanogens: reevaluation of a unique biological group. Microbiol. Rev. 43:260-296.

3. Barker, H. A. 1936. Studies upon the methane-producing bacteria. Arch. Mikrobiol. 7:420-438.

4. Breed, R. S., E. G. D. Murray, and N. R. Smith (ed.). 1957. Bergey's manual of determinative bacteriology, 7th ed. The Williams \& Wilkins Co., Baltimore.

5. Bryant, M. P. 1974. Methane-producing bacteria, p. 472-477. In R. E. Buchanan and N. E. Gibbons (ed.), Bergey's manual of determinative bacteriology, 8th ed. The Williams \& Wilkins Co., Baltimore.

6. Groenewege, J. 1920. Bakteriologische Untersuchungen uber biologische Reinigung. Bull. Jard. Bot. Buitenzorg Ser. 3 2:203236.

7. Kluyver, A. J., and C. B. van Niel. 1936. Prospects for a natural system of classification of bacteria. Zentralbl. Bakteriol. Parasitenkd. Infektionskr. Hyg. Abt. 2 94:369-403.

8. Lapage, S. P., P. H. A. Sneath, E. F. Lessel, V. B. D. Skerman, H. P. R. Seeliger, and W. A. Clark (ed.). 1975. International code of nomenclature of bacteria. 1975 Revision. American Society for Microbiology, Washington, D.C.

9. Mah, R. A. 1980. Isolation and characterization of Methanococcus mazei. Curr. Microbiol. 3:321-326.

10. Mazé, P. 1915. Ferment forménique. Fermentation forménique de l'acétone. Procédé de culture simple du ferment forménique. C. R. Seances Soc. Biol. Ses Fil. 78:398-405.

11. Skerman, V. B. D., V. McGowan, and P. H. A. Sneath (ed.). 1980. Approved lists of bacterial names. Int. J. Syst. Bacteriol. 30:225-420.

12. Stadtman, T. C., and H. A. Barker. 1951. Studies on the methane fermentation. X. A new formate-decomposing bacterium, Methanococcus vannielii. J. Bacteriol. 62:269-280.

13. Zhilina, T. N. 1976. Biotypes of Methanosarcina. Microbiology (U.S.S.R.) 45:414-421.

14. Zhilina, T. N., and G. A. Zavarzin. 1979. Cyst formation by Methanosarcina. Microbiology (U.S.S.R.) 48:349-354.

15. Zinder, S. H., and R. A. Mah. 1979. Isolation and characterization of a thermophilic strain of Methanosarcina unable to use $\mathrm{H}_{2}-\mathrm{CO}_{2}$ for methanogenesis. Appl. Environ. Microbiol. 38:9961008 . 